\title{
Determining the Isotopic Composition of Nitrate in the River Daugava and Loads of Nitrogen to the Gulf of Riga
}

\author{
Arturs Skute $^{1}$, Sergejs Osipovs ${ }^{2}$, Davids Vardanjans ${ }^{3}$ \\ ${ }^{1}$ Armgate Ltd., Liliju 20, Marupe, Riga District, LV-2167, Latvia, \\ ${ }^{2}$ Daugavpils University, Parades 1A, Daugavpils, LV-5401, Latvia, \\ ${ }^{3}$ Armgate Ltd., Liliju 20, Marupe, Riga District, LV-2167, Latvia
}

\begin{abstract}
The Daugava or Zapadnaya (Western) Dvina River belongs to the Baltic Sea basin. The length of the river is $1,005 \mathrm{~km}$ with a drainage area of $87,900 \mathrm{~km}^{2}$. It crosses three countries: Russia $\left(323 \mathrm{~km}\right.$ and $\left.18,500 \mathrm{~km}^{2}\right)$, Belarus $\left(328 \mathrm{~km}\right.$ and $\left.33,100 \mathrm{~km}^{2}\right)$ and Latvia $\left(352 \mathrm{~km}\right.$ and $\left.24,700 \mathrm{~km}^{2}\right)$. Water samples were collected at three points with the following coordinates: Kraslava, Daugavpils, and Riga and distance from the river mouth 320, 255, and 20 km respectively. Discharge measurements by use of acoustic Doppler current profiler (ADCP) from a moving boat were also performed in the locations indicated above. Nitrates were extracted from water samples using the 'ionexchange resin method', which involves extracting $\mathrm{NO}_{3}^{-}$from freshwater and converting it into solid silver nitrate, which is then analysed for ${ }^{15} \mathrm{~N} /{ }^{14} \mathrm{~N}$ and ${ }^{18} \mathrm{O} /{ }^{16} \mathrm{O}$ ratios by IRMS. Prior to passing water through an anion-exchange resin precipitation of $O$-bearing contaminants (mainly sulphate and phosphate) with barium chloride was carried out. The $\delta^{15} \mathrm{~N}_{\mathrm{NO}}$ values of riverine samples varied from 7.1 to $8.6 \%$ in Kraslava, from 7.2 to $8.3 \%$ in Daugavpils, and from 8.1 to $9.0 \%$ in Riga and displayed significant differences between the three sampling points.
\end{abstract}

Keywords: nitrates; stable isotopes; ion exchange.

\section{INTRODUCTION}

Like the Earth's water, nitrogen compounds cycle through the air, aquatic systems, and soil. However, unlike water, these compounds are being injected into the environment in ever increasing quantities. In doing so, humans alter the global nitrogen cycle, causing possible grave impacts on biodiversity, global warming, water quality, human health, and even the rate of population growth in developing nations. In natural environments, the availability of nitrogen is often limited by the rate of $\mathrm{N}$-fixation. Nitrogen availability is one of the main controls on productivity and is an important factor regulating biodiversity [1]. Presently, $\mathrm{N}$ input from human sources, chiefly Nfixing crops, synthetic fertilizers, and burning of fossil fuels, approximately equals the input from natural nitrogen fixation [2]. The increased $\mathrm{N}$ input from anthropogenic sources causes eutrophication of lakes, streams, and coastal waterways, acidification of susceptible environments, and degradation of drinking water quality [3].

Nitrogen and oxygen isotope ratios of nitrate provide a powerful tool to investigate nitrate sources and cycling mechanisms. The analysis of nitrate for both $\delta^{15} \mathrm{~N}$ and $\delta^{18} \mathrm{O}$ allows improved discrimination among potential sources and reaction mechanisms $[4,5]$.
In our time, $\delta^{15} \mathrm{~N}-\mathrm{NO}_{3}{ }^{-}$and $\delta^{18} \mathrm{O}-\mathrm{NO}_{3}{ }^{-}$in nitrate can be measured according to three analytical methods [6]: two 'denitrifier methods' requiring Isotope Ratio Mass Spectrometry (IRMS) analysis of $\mathrm{N}_{2} \mathrm{O}$ gas generated by bacterial or chemical means, and a procedure known as the 'ion-exchange resin method' whereby $\mathrm{NO}_{3}^{-}$is extracted from freshwater and converted into solid silver nitrate $\left(\mathrm{AgNO}_{3}\right)$ that is analysed by IRMS [7]. Minor modifications have been adopted by some to ease the sample preparation [8], one of the most significant changes being the precipitation of O-bearing contaminants (mainly sulphate and phosphate) with barium chloride $\left(\mathrm{BaCl}_{2}\right)$ prior to passing water through an anion-exchange resin so that $\mathrm{AgNO}_{3}$ is ready for both $\delta^{15} \mathrm{~N}$ and $\delta^{18} \mathrm{O}$ analyses [9].

The objectives of the research proposal are to use isotope data for nitrate as a tool for determining nitrate sources in river systems, while also evaluating how natural variation in water discharge can influence seasonal changes of nutrient loads and isotopic values.

\section{MATERIALS AND METHODS}

\section{A. Sample preparation}

The Daugava or Zapadnaya (Western) Dvina River belongs to the Baltic Sea basin. The length of the river 
is $1,005 \mathrm{~km}$ with a drainage area of $87,900 \mathrm{~km}^{2}$. It crosses three countries: Russia $(323 \mathrm{~km}$ and 18,500 $\mathrm{km}^{2}$ ), Belarus (328 $\mathrm{km}$ and $\left.33,100 \mathrm{~km}^{2}\right)$ and Latvia $\left(352 \mathrm{~km}\right.$ and $\left.24,700 \mathrm{~km}^{2}\right)$. Mean annual Daugava River water runoff is $710 \mathrm{~m}^{3} \mathrm{~s}^{-1}$. Mean annual riverine loads of $\mathrm{N}-\mathrm{NO}_{3}{ }^{-}$is 27.4 thousand tons per year at discharge $23.27 \mathrm{~km}^{3} \mathrm{yr}^{-1}[10,11]$.

Water samples were collected at three points with the following coordinates: Kraslava $\left(55^{\circ} 53^{\prime} 22^{\prime \prime} \mathrm{N}\right.$;

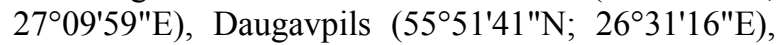
Riga $\left(56^{\circ} 54^{\prime} 18^{\prime \prime} \mathrm{N} ; 24^{\circ} 11^{\prime} 01 " \mathrm{E}\right)$ and distance from the river mouth 320,255 , and $20 \mathrm{~km}$ respectively. Discharge measurements by use of acoustic Doppler current profiler (ADCP) from a moving boat were also performed in the locations indicated above. Samples were collected with 2 litres HDPE bottles in the middle of the river at $1 \mathrm{~m}$ depth, the parallel were collected three samples.

In first, $\mathrm{NO}_{3}^{-}$concentrations are measured to determine how much water needs to be processed to retain $100-200 \mu \mathrm{mol}$ of nitrate (i.e. $6.2-12.4 \mathrm{mg} \mathrm{NO}_{3}{ }^{-}$) on the anion exchange resin. The sample water is then filtered through a $0.45 \mu \mathrm{m}$ nylon membrane to remove particles that might clog the resin. In reference method [7] for the removal of O-bearing contaminants to the sample added of $4 \mathrm{~mL}$ of $1 \mathrm{M} \mathrm{BaCl}_{2}$ (large excess) to precipitate sulphate (up to $4000 \mu \mathrm{mol}$ ) and phosphate to a lesser extent (levels typically low in sub-surface water), stored at $4^{\circ} \mathrm{C}$ overnight, filtered through a 0.2 $\mu \mathrm{m}$ nylon membrane. Sulphate removal is crucial because sulphate has a higher affinity for the resin than nitrate (according to the resin manufacturer). We modified method and added $\mathrm{BaCl}_{2}$ after $\mathrm{NO}_{3}{ }^{-}$was stripped from the columns.

Sample passed through the anion exchange resin column (2 mL Bio-Rad AG1-X8, 200-400 mesh in $\mathrm{Cl}^{-}$ form, capacity of $1200 \mu \mathrm{eq} \mathrm{mL}^{-1}$, pre-conditioned by dripping through $4 \mathrm{~mL}$ of $1 \mathrm{M} \mathrm{HCl}$ and rinsed) at a flow rate of $500-1000 \mathrm{~mL} \mathrm{~h}^{-1}$ is achieved by adjusting the stopcock on the separatory funnel. Resin is then rinsed and column is filled with deionized water, and stored at $4^{\circ} \mathrm{C}$ until later elution. The resin was kept wet at all times. This steps completed in the laboratory within 48 hours of collection [7].

The $\mathrm{NO}_{3}{ }^{-}$is stripped from the columns by five $3 \mathrm{~mL}$ increments of $3 \mathrm{M} \mathrm{HCl}$ passed through the column (elutant kept chilled to minimise volatilisation of $\mathrm{HNO}_{3}$ ), each increment kept in the column for 30 seconds before slowly blowing the column dry, rinsing (whole step carried out in the dark) [9]. Elutant immediately neutralised by slow addition of about $6 \mathrm{~g}$ of silver oxide (three different batches of high-grade $\mathrm{Ag}_{2} \mathrm{O}$ heavily contaminated with nitrate were previously washed [7]) until $\mathrm{pH}$ reached 5-6 (checked with $\mathrm{pH}$-paper), filtration through a $0.2 \mu \mathrm{m}$ nylon membrane to remove excess $\mathrm{Ag}_{2} \mathrm{O}$ and silver chloride $(\mathrm{AgCl})$, rinsing (whole step carried out in the dark). $\mathrm{AgNO}_{3}$ solutions (about $40 \mathrm{~mL}$ ) frozen at $-75^{\circ} \mathrm{C}$, then freeze-dried in the dark (and stored in amber vials in a desiccator).

\section{B. IRMS measurements}

For oxygen isotope analysis an aliquots of the samples $(1.0 \pm 0.1 \mathrm{mg}$ amounts) were weighed into silver capsules $(8 \times 5 \mathrm{~mm})$. Oxygen isotope analysis was conducted by total conversion at $1080^{\circ} \mathrm{C}$ in a quartz reactor tube lined with a glassy carbon film, filled to a height of $170 \mathrm{~mm}$ with glassy carbon chips and topped with a layer of $50 \%$ nickelized carbon (10 mm deep). Carbon monoxide and nitrogen were separated on a GC column packed with molecular sieve $5 \mathrm{~A}$ at a temperature of $60^{\circ} \mathrm{C}$. The IRMS used was a Europa Scientific 20-20 with triple Faraday cup collector array to monitor the masses 28,29 and 30 .

For nitrogen isotope analysis an aliquots of the samples (2.0 $\pm 0.3 \mathrm{mg}$ amounts) were weighed into tin capsules $(8 \times 5 \mathrm{~mm})$. Analysis was undertaken by EAIRMS (Elemental Analyser Isotope Ratio Mass Spectrometry). Tin capsules containing sample or reference material wereu loaded into an automatic sampler on a Europa Scientific RoboPrep-CN elemental analyser, from where they are dropped in sequence into a furnace held at $1000^{\circ} \mathrm{C}$ and combusted in an oxygen rich environment. The tin capsules flash combust, raising the temperature in the region of the sample to ca. $1700^{\circ} \mathrm{C}$. The gases produced on combustion are swept in a helium stream over combustion catalyst $\left(\mathrm{Cr}_{2} \mathrm{O}_{3}\right)$, copper oxide wires (to oxidize hydrocarbons), and silver wool to remove sulphur and halides. For nitrogen- 15 analysis, $\mathrm{CO}_{2}$ is removed using a Carbosorb chemical trap and the nitrogen focused on packed column gas chromatograph held at a constant temperature of $100^{\circ} \mathrm{C}$. The resultant $\mathrm{N}_{2}$ chromatographic peak enters the ion source of a Europa Scientific 20-20 IRMS where it is ionized and accelerated. Gas species of different mass are separated in a magnetic field then simultaneously measured using a Faraday cup collector array set to monitor masses 28,29 and 30 .

\section{RESULTS AND DISCUSSION}

\section{A. Compositions of river water samples}

Nitrate concentration was determined by flow analysis (FIA) and spectrometric detection method. Analysis was undertaken by FIALab-2500. Levels of nitrate nitrogen in first sampling point - Kraslava is ranged between 0.15 and $1.58 \mathrm{mg} \mathrm{L}^{-1}$, in second point Daugavpils is ranged between 0.43 and $1.75 \mathrm{mg} \mathrm{L}^{-1}$, and at the third location - Riga it is in the range between 0.79 and $2.23 \mathrm{mg} \mathrm{L}^{-1}$ (Fig. 1). 


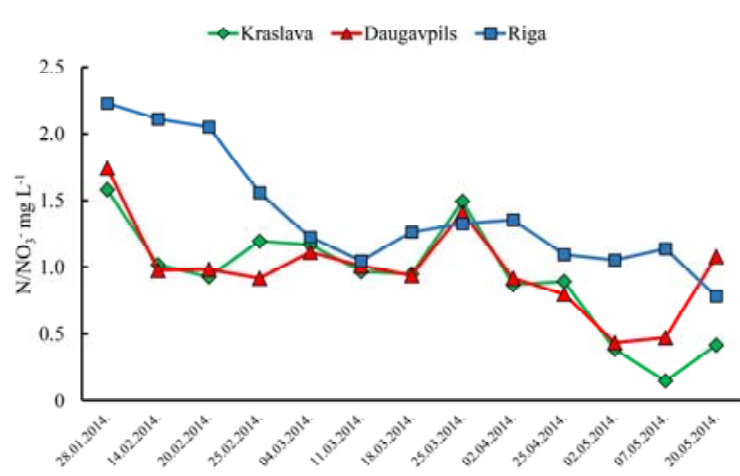

Fig. 1. Changes in $\mathrm{N} / \mathrm{NO}_{3}$ at the depth of $1 \mathrm{~m}$ in Daugava river over the period between January 28 and May 20, 2014 in Kraslava, Daugavpils, and Riga.

$\% \mathrm{~N}$ measured in $\mathrm{AgNO}_{3}$ prepared from field water samples ranged from 1.5 to 8.1 (median of 7.5), with $90 \%$ of these samples showing $\% \mathrm{~N}$ between 6.9 and 8.1. \% O measured in $\mathrm{AgNO}_{3}$ ranged from 20.1 to 28.7 (median of 28.2), with $90 \%$ of these samples showing $\% \mathrm{O}$ between 27.7 and 28.7 .

In winter, the largest differences were observed in the hydrological regime between sampling points. The $\delta^{15} \mathrm{~N}_{\mathrm{NO} 3}$ values of riverine samples taken in winter varied from 7.1 to $8.6 \%$ in Kraslava, from 7.2 to 8.3 \%o in Daugavpils, and from 8.1 to $9.0 \%$ in Riga (Fig. 2) and displayed significant differences between the three sampling points.

The data obtained for Kraslava, Daugavpils, and Riga for $\delta^{15} \mathrm{~N}_{\mathrm{NO} 3}$ values and $\delta^{18} \mathrm{O}_{\mathrm{NO} 3}$ values are given in Table 1 .
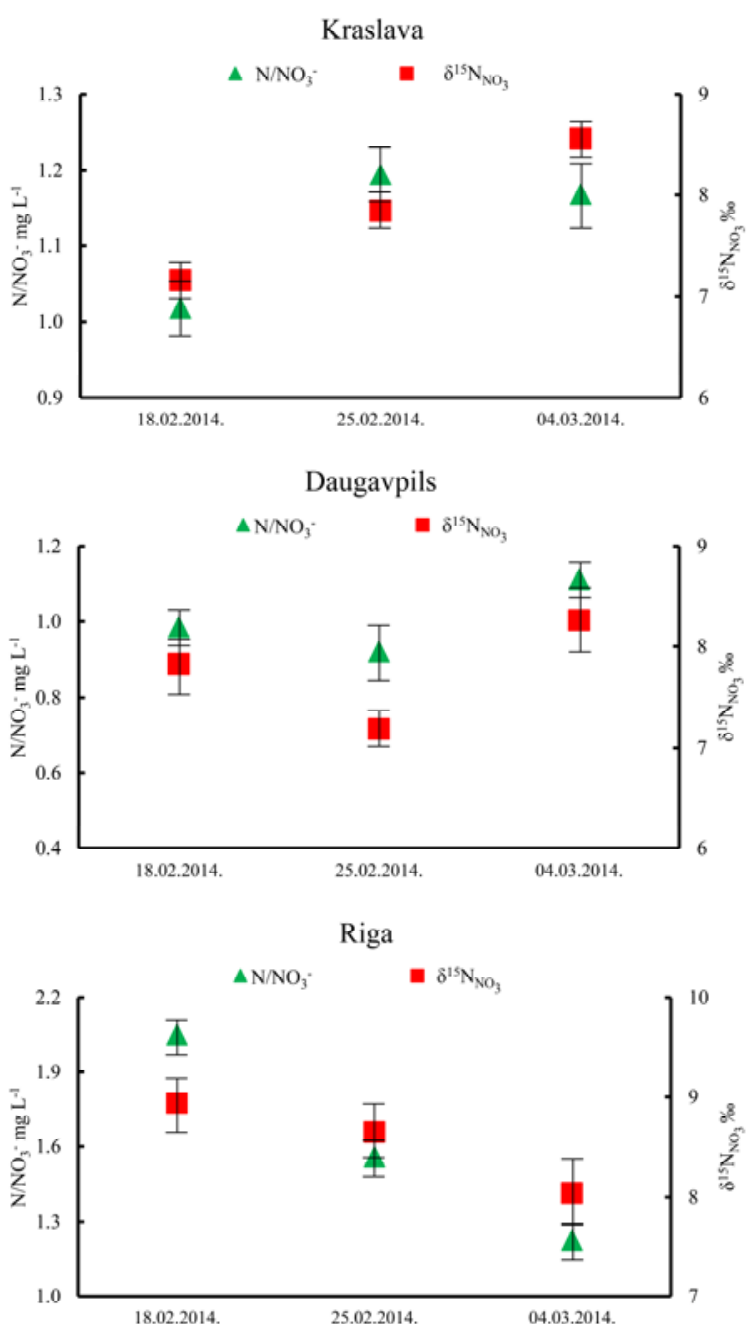

Fig. 2. Nitrate nitrogen concentration and isotopic composition of $\mathrm{N}$ in Kraslava, Daugavpils, and Riga.

TABLE I

SUMMARY OF THE CHARACTERISTICS OF RIVER DAUGAVA. AVERAGE VALUES AND STANDARD DEVIATIONS ARE GIVEN FOR THREE REPLICATE RUNS

\begin{tabular}{|c|c|c|c|c|}
\hline Date & Sampling point & $\mathrm{N} / \mathrm{NO}_{3}{ }^{-}\left[\mathrm{mg} \mathrm{L}^{-1}\right]$ & $\delta^{15} \mathrm{~N}_{\mathrm{NO} 3}[\% 0]$ & $\delta^{18} \mathrm{O}_{\mathrm{NO} 3}[\% \mathrm{o}]$ \\
\hline \multirow[t]{3}{*}{ 18.02.2014. } & Kraslava & $1.02 \pm 0.07$ & $7.16 \pm 0.38$ & $3.65 \pm 0.17$ \\
\hline & Daugavpils & $0.98 \pm 0.09$ & $7.83 \pm 0.23$ & $5.89 \pm 0.21$ \\
\hline & Riga & $2.05 \pm 0.17$ & $8.94 \pm 0.22$ & $5.07 \pm 0.19$ \\
\hline \multirow[t]{3}{*}{ 25.02.2014 } & Kraslava & $1.19 \pm 0.09$ & $7.84 \pm 0.28$ & $3.99 \pm 0.09$ \\
\hline & Daugavpils & $0.92 \pm 0.03$ & $7.19 \pm 0.12$ & $5.40 \pm 0.11$ \\
\hline & Riga & $1.56 \pm 0.04$ & $8.65 \pm 0.24$ & $6.19 \pm 0.15$ \\
\hline \multirow[t]{3}{*}{ 04.03.2014. } & Kraslava & $1.17 \pm 0.11$ & $8.56 \pm 0.19$ & $5.49 \pm 0.18$ \\
\hline & Daugavpils & $1.11 \pm 0.12$ & $8.26 \pm 0.15$ & $5.42 \pm 0.14$ \\
\hline & Riga & $1.23 \pm 0.06$ & $8.04 \pm 0.27$ & $5.58 \pm 0.12$ \\
\hline
\end{tabular}

Nitrate nitrogen concentrations were significantly positively correlated with $\delta^{15} \mathrm{~N}_{\mathrm{NO} 3}$ values in Kraslava, Daugavpils, and Riga $(\mathrm{R}=0.8)$. The liner equation describe the correlation between Isotopic tracers and nitrates with linear regression coefficient $\left(R^{2}=0.62\right)$
(Fig. 3). The relation of $\delta^{15} \mathrm{~N}_{\mathrm{NO} 3}$ used to distinguish between sources of nitrates. The first source could be related to $\mathrm{NO}_{3}{ }^{-}$leaching from non-fertilized soils usually having $\delta^{15} \mathrm{~N}_{\mathrm{NO} 3}$ values in the range from -3 to $5 \%$. The second nitrate source with a higher $\mathrm{NO}_{3}^{-}$ 
concentration and $\delta^{15} \mathrm{~N}_{\mathrm{NO} 3}$ value could be related to nitrate $\mathrm{N}$ leaching from manured agricultural areas and/or to nitrate $\mathrm{N}$ derived from sewage. $\mathrm{NO}_{3}{ }^{-}$ originating from animal manure and sewage generally shows $\delta^{15} \mathrm{~N}_{\mathrm{NO} 3}$ value $>7 \%$.



Fig. 3. The relation between $\delta^{15} \mathrm{~N}_{\mathrm{NO} 3}$ values and $\mathrm{NO}_{3}{ }^{-}$ concentrations in the Daugava River

\section{CONCLUSIONS}

The results suggesting that $62 \%$ of variability in the $\delta^{15} \mathrm{~N}_{\mathrm{NO} 3}$ values could be attributed to mixing of $\mathrm{NO}_{3}{ }^{-}$ from two sources: from non-fertilized soils and from manured agricultural areas.

\section{ACKNOWLEDGMENTS}

This study was supported by Cohesion Fund (KF) project "Seasonal changes of nutrient load in the catchment area of Gulf of Riga” No. L-KC-11-0005.

\section{REFERENCES}

[1] R.W. Howarth, G. Billen, D. Swaney, A. Townsend, N. Jarowski, K. Lajtha, J.A. Downing, R. Elmgren, N. Caraco, T. Jordan, F. Berendse, J. Freney, V. Kudeyarov, P. Murdoch and Z. Zhao-Liang, in Nitrogen cycling in the North Atlantic Ocean and its Watersheds, edited by R.W. Howarth (Kluwer Academic Publishers, 1996), pp. 75-139.

[2] J.N. Galloway, W.H. Schlesinger, H. Levy, A. Michaels and J.L. Schnoor, Global Biochem. Cy. 9, 235 (1995)

[3] P.M. Vitousek, J.D. Aber, R.W. Howarth, G.E. Likens, P.A. Matson, D.W. Schindler, W.H. Schlesinger, D.G. Tilman, Human alteration of the global nitrogen cycle: sources and consequences, Ecol. Appl. 7 (3) (1997) 737-750.

[4] A. Amberger, H.-L. Schmidt, Natürliche Isotopengehalte von Nitrat als Indikatoren für dessen Herkunft, Geochim. Cosmochim. Acta 51 (1987) 2699-2705.

[5] J. Boettcher, O. Strebel, S. Voerkelius, H.-L. Schmidt, Using isotope fractionation of nitrate-nitrogen and nitrateoxygen for evaluation of microbial denitrification in a sandy aquifer, J. Hydrol. 114 (1990) 413-424.

[6] D. Xue, J. Bottle, B. De Baets, F. Accoe, A. Nestler, P. Taylor, O. Van Cleemput, M. Berglund, P. Boeckx, Present limitations and future prospects of stable isotope methods for nitrate source identification in surface- and groundwater, WaterRes. 43 (2009) 1159-1170.

[7] S. R. Silva, C. Kendall, D. H. Wilkison, A. C. Ziegler, C. C. Y. Chang, R. J. Avanzino, A new method for collection of nitrate from fresh water and analysis of the nitrogen and oxygen isotope ratios, J. Hydrol. 228 (2000) 22-36.

[8] R. D. Stickrod, J. D. Marshall, On-line nitrate- $\delta 15 \mathrm{~N}$ extracted from groundwater determined by continuous-flow elemental analyzer/isotope ratio mass spectrometry, Rapid Commun. Mass Spectrom. 14 (2000) 1266-1268.

[9] E. Minet, R. Goodhue, C. E. Coxon, R. M. Kalin, W. MeierAugenstein, Simplifying and improving the extraction of nitrate from freshwater for stable isotope analyses, J. Environ. Monit. 13 (2011) 2062.

[10] A. Yurkovskis, F. Wulff, L. Rahm, A. Andruzaitis, M. Rodriguez- Medina, Estuar. Coast. Shelf. S. 37, 113 (1993)

[11] A. Andrushaitis, Z. Seisuma, M. Legzdina, A. Lenshs, in Ecosystem of the Gulf of Riga between 1920 and 1990, edited by E. Ojaveer (Estonian Academy of Sciences, Tallinn, Estonia, 1995), pp. 32-40. 